versity, that these calm, quiet, but true emotions, can be understoodnay, conceived.

But I must apologise for having allowed my thoughts to have for an instant led me away from my subject; and, without further reflections, I will go on with the narrative of our journey, considered specially in its medical aspect. To give a description of all the diseases of the country, of the various native modes of treatment, of the peculiar native customs, of the geology, Flora, etc., would be quite beyond the limits of these papers. I propose, therefore, to select from my notes some as yet unpublished details, which will, under a more readable form than a long, dry dissertation, give, I hope, a clear idea of the several points most interesting to the profession.

After leaving Metemma, we passed at once into a hilly country, and on the 3Ist of December we encamped about half way between the high range above us and Metcmma, now almost at our feet, at a place called Bal Waha. From the day we left the Soudan, we never had occasion to complain of the quantity and quality of the water-supply; although in certain localities it may be deemed insufficient for an army or a large body of men, we ourselves always found it good and abundant.

At Bal Waha we had to remain several days, until the escort and the bearers sent by the King arrived. Bal Waha seems to have been, during Theodore's reign, a kind of half-way house, a second-class " Hotel des Ambassadeurs"-first rank, of course-belonging to Magdala. A clear running stream (how we loved it!) divides the valley into almost two equal halves. We were shewn first the spot which poor Abdul Rahman Bey, the Turkish Ambassador, had a few years before selected for himself and party; and, by a kind of superstitious feeling, we moved further on, halting in the next open space, as yet associated with no record of treachery and unmerited misfortune. However, for all that our fate was even worse than our predecessors'. I have advanced elsewhere a fact that has been contradicted ; namely, that Abyssinians, as a race, are cruel. Travellers but too frequently see but the smiles of those who constantly fawn on them, in the hopes of receiving presents; and, in stead of studying the native chez lui, they judge him merely by his conduct towards themselves.

First impressions are generally true; and on New Year's day of 1866 , for the first time, we saw a certain number of Abysinians around us; and the manner they killed a cow which we had given them as a treat, made me feel that they must be cruel, or, what is very much the same, devoid of all sensibility, and taking pleasure in witnessing the sufferings of others, be they men or beasts.

In Abyssinia, every one who carries a sword is a butcher, and delights in the work. On the occasion I mention, the "amateur" butcher was one of our former messengers, named Hailo. Probably being of a poor family, he had not killed many cows before; and, to all appearance, was not well up to his work. Being in a great hurry to obtain, as soon as possible, a slice of the warm and thrilling flesh, he did not bind the animal's legs properly; and, no sooner was the cow knocked down, and kept apparently quict and helpless by some five or six hungry fellows sitting upon it, than Hailo, in the name of the Father, the Son, and the Holy Ghost, proceeded with a blunt sword to cut the animal's throat. But the cow, not approving of the utter sans gène displayed in an operation of such vital importance to herself, tossed off the fellow sitting on her head, and with a kick sent howling away a great big muleteer, who was at the time pulling on the tail with all his might. Imbued with fresh courage by her easy victory, the cow disengaged herself entirely from her terrified enemies, and, with the blood streaming from the wound in her neck, she made straight for a neighbouring thicket, secking in its solitude safety against the crowd. The Abyssinians, after the first moment of surprise, rallied, and, exciting one another with shrieks and war-cries, followed after it. With a good deal of caution they surrounded her, and for some minutes the belligerents stood gazing at one another. Evidently with the loss of blood her warlike spirits seemed to have vanished, and her now pleading eye had nought of its momentary fury. One of the bravest Abyssinians advanced on tip-toe noiselessly from behind, and, with a blow of his sword, endeavoured to ham-string the poor brute. Too much caution, caused by a lurking fear that the cow misht turn round, had somewhat arrested the violence of the blow; the cow was severely wounded, but the tendon was not severed. Off she started again, the crowd this time following closely upon her steps. Swords, spears, stones, were now freely used; and the poor brute, red with blood and covered with wounds, fell down in great agony. The Abyssinians, forgetting their hunger, enjoyed the fun immensely; they laughed, shrieked, in their delight danced around her; and for a while they were so excited that they positively refused to allow me to interfere and put an end to their sport; but I would not listen, and a bullet through her heart put an end to that disgraceful and disgusting scene. No sooner had I fired than a great rush was made; it was of all importance that before life should be completely extinct the mystic invocation should be repeated, otherwise no good Abyssinian Christian could partake of the flesh without fear of eternal damnation.

But it may possibly be suggested that this is an exceptional case, and proves nothing. I will therefore, in the next paper, adduce some native customs and habits bearing upon this point.

\section{ON THE MANAGEMENT OF DIET IN DISEASE.}

\author{
By JOHN BEDDOE, B.A., M.D., \\ Physician to the Bristol Royal Infirmary; Consulting Physician to the Bristol \\ Children's Hospital; etc.
}

IN taking up this extensive subject, I have no intention of attempting to treat even a portion of it exhaustively : my aim is simply to bring forward a few general considerations bearing upon it, and afterwards to discuss, suggestively, some points in the dietetic treatment of certain diseases.

It is noteworthy how seldom and how sparingly the subject has been treated from this point of view. The dietetic management of diabetes and of gout has indeed been a favourite topic with writers on those diseases, and writers on continued fever have usually attributed its fair share of importance to the conduct of the dietary; but when other morbid states, not directly affecting the stomach, are treated of, the diet is usually dismissed as briefly as possible. It is not long since Dr. Fuller, in a paper read before the London Medical Society, complained with justice that the reporters of cases, while revelling in the minutest particulars of history or pathological anatomy, usually omitted or slurred over all account of the treatment-medicinal or dietetic-which had brought the patient to the post mortem room, or at least failed to keep him out of it. The fact was at once a cause and a consequence, Dr. Fuller implied, of the backward state of the study of therapeutics among us. Certainly this particular department of therapeutics is not in advance of other portions of that science. We have many works on food and diet-some written for the profession, more for the public; but they almost all conform, with more or less strictness, to one model. The classification and chemical constitution of various aliments are laid down positively, minutely, and copiously; but the instructions for their employment in disease are scanty and hazy in the extreme. The reason of all this is obvious enough. If the application of principles of dietary to particular diseases is, with the exceptions above mentioned, so very rare, we naturally conclude that such principles are uncertain or awanting. We have in truth almost as little exact knowledge about the use and effects of foods as we have about those of drugs.

The same conclusion is pointed at by what may at first sight appear to be contrary instances. When Dr. Edward Smith or Dr. Dobell publishes an exactly specified ration, or two or three such rations, for consumptive patients, we remember the great variety of conditions, as regards capacity to take and digest food, and to be favourably or unfavourably affected by various kinds of aliment, in which our consumptive patients exist; and the attempt to apply to them such Procrustean rules leads us to suspect the narrowness or one-sidedness of the views on which the rules are hased.

It seemed, not long ago, as though all the questions connected with the use of alcohol were likely to be withdrawn from the realm of dietetics, by the discovery of Lallemand that alcohol was not a food, but a medicine incapable of decomposition in the system. Certainly the observations on which this theory was based did not afford a sufficient basis for it; but even if they had done so, one would have been justified in denying, or at least doubting, the accuracy of those observations, so contrary were the views that sprang from them to the evidence of common experience. But the experiments of Dr. Anstie, while diminishing the value of those of Lallemand, and utterly overthrowing the theory based thereon, promise to afford us, if confirmed, a new and most important principle in dietetics-nothing less, in short, than a practical rule for the administration or denial of wine, based on a pathological principle. It is, I repeat, a curious and lamentable consideration, how few such rules are the common property of the profession. Stokes's single and excellent rule for commencing the administration of wine in continued fever, when the first sound of the heart approaches the second in quality, is one of the most valuable and best known. The work of Fonssagrives on Alimentary Hygiene, probably the best of its kind in any language, certainly contains more of such practical and valuable precepts than any English one, though our national vanity may be consoled by finding some of them referred to our compatriots Huxham and Sydenham, such as the precept that in all fevers the patient should drink very much, very frequently, and but little at a time.

On the other hand, our national susceptibilities or prejudices may be shocked, on reading, a little further on in the pages of Fonssagrives, a 
most trenchant condemnation of our fashionable modes of dietetic treatment in fever. "Dr. Todd", he says, "treated almost all his fevers by the association of a succulent regimen, of which beef-tea began the series, with considerable doses of alcoholic drinks; and he claimed a success which rather exhibited the long-suffering of nature, who took the pains to resist such dietetic brutalities, than the prudence of the practice that put them in force. Nor was Graves less absolute nor less ardent in his crusade against the Hippocratic abstinence; and he was so proud of feeding fevers that he expressly desired that this principle, which must have sent so many patients to the tomb, should figure dogmatically as an inscription upon his own."

Fonssagrives himself, like most of the French physicians, follows, in typhoid fever, what he calls " the traditional prescriptions of the Hippocratic diet"- -utter abstinence during the early days of the fever, liquid aliments only afterwards; and, some time later, when the crisis of the fever is past, a gradual and well-managed transition to more substantial food. When we recollect that the French in general are very ready to allow wine to their patients where we are content with milder fluids, we shall interpret the phrase liquid aliments as inclusive of a little wine more or less diluted. Thus understood, the practice of Fonssagrives, which he allows to be less rigorous as to abstinence than that of some of his compatriots, will differ from our own chiefly with respect to the few early days of the attack. There are, I suppose, none of us on this side of the Channel who do not allow during that period milk, barleywater, and other such thin and unstimulant potations. There are, how ever, cases in which every kind of fluid is included among objects of loathing by the patient, and in such it might possibly be proper, for two or three days at least, to follow the indication of Nature, so long as the urine is tolerably healthy, except as to concentration. Usually, however, ice and iced water are not unpleasant to the patient, even when the perversion of taste renders all other fluids positively nauseous. I am by no means certain that the small quantities of nourishment which we manage to introduce during the first few days are of any real service. They are, no doubt, usually absorbed into the vessels; but whether they are subsequently employed in the economy for any useful purpose, or are cast out in the excretions, may admit of some doubt-doubt that might be solved by a careful comparative examination in a sufficient number of suitable cases.

During the middle period of enteric fever, there is not much disagreement, except as to the quantities of wine advisable, and the stage at which its use should be commenced. It is here that Dr. Stokes's rule is so valuable; but Dr. Anstie, if he should fulfil his expectations, will furnish us with another, equally valuable and more precise. I agree with Dr. Gairdner in believing that a great number of enteric fever cases, including most of those under twenty or twenty-five years of age, get through as well, or better, without wine, though at more advanced ages it can more rarely be dispensed with. I agree with him, too, in thinking that the copious use of alcoholic stimulants tends to prolong the duration of the fever, probably by lessening elimination, and thus retaining the fever-poison in the system. I think I have seen the same prolongation in typhus under like circumstances.

The copious use of beef-tea may now be said to be a matter of rule in enteric fever. It is doubtful whether it is not often pushed too far. As usually prepared, it may be defined as a weak solution of the saline constituents of flesh, including some, as kreatine, which appear to be simply waste products ready for excretion. I can see that some of the saline matters may be of the greatest possible use during convalescence, when they may help on the process of building up new tissue; but there is no reason to suppose that during the acme of the fever the salts waste faster than the albuminoid constituents of the body and blood; and it is difficult, therefore, to see how any large quantities of beef-tea can be useful then, except by their ill-understood stimulant action, while they may often prove positively hurtful by exciting diarrhœa. I therefore, regarding it as a stimulant rather than as a food, make but moderate use of beef-tea during the middle period, and trust mainly to iced milk, or milk with lime-water, which, as fluid, cool, grateful, bland, nutritious and readily digested, free of tendency to promote diarrhœa, and containing as much saline matter as seems requisite, is indicated as the best of all possible foods, except for persons of peculiar idiosyncrasy.

Where we have reason to suspect the existence of intestinal ulcers, that is, in the general run of cases, it is usually and rightly laid down that solid food should not be given until convalescence is somewhat advanced. This rule is, however, extremely vague. The stage of the case meant may perhaps be best indicated by the tongue and the stools having resumed their natural aspect, and kept the same for two or three days. A definition of the word solid is also needed. Is well-baked bread a solid in this sense? Scarcely; for, by the time the products of its digestion reach the ileum, they must be indistinguishable from those of any farinaceous liquid. But close, tenacious, ill-baked bread may, as I am reminded by Dr. Symonds, pass undigested and in bulk into the ileum. It may generally be allowed in small quantity as soon as the patient desires it. But flesh meat and fish are the solids especially pointed at in the rule just mentioned : the use of vegetables must be deferred to a later period still.

Among the heresies with respect to acute rheumatism which have lately arisen in this country, has been that of dieting the patients on meat and wine in liberal quantities. Of course, like all new procedures, it succeeded very well in the hands of those who tried it. For my own part, I have seldom departed from my usual plan of confining the patient to farinacea and milk, with perhaps a little beef-tea, without seeing reason, or thinking I saw reason, to repent it. If the poison of acute rheumatism be lactic acid, it is somewhat strange that milk does not disagree, while wine, according to my experience, almost always does.

There appears to be some room for doubting what is the proper diet for patients under active treatment for constitutional syphilis. I have usually procecded, as I suppose most men do, on the principle that, as the disease itself is a lowering one, and the medicines used in the hope of eliminating the poison are mostly of the destructive class, their operation should be balanced by that of a liberal dietary. In many cases of tertiary affections, this view is pressed very forcibly upon us by the dread of the development of phthisical disease. But in Sweden anci elsewhere the effects of an extremely restricted diet--the hunger-cure; as it is termed-are said to have been found singularly beneficial. And Professor Sigmund, the eminent syphilologist of Vienna, used to insist on a low and scanty, though not cxactly a starvation diet, during the treatment of his patients by mercurial inunction.

$A$ few words on the dictetic treatment of jaundice, and I have done: Frerichs says nothing on the subject, beyond advising the use of a regimen consisting mainly of easily digested animal food with vegetables ; his object being purely, it would seem, to obviate discomfort from flatulence and constipation. In several of his clinical histories he notices the fact that the appetite of the patient was unaffected. I think we may go beyond that statement, and say that in many cases of jaundice, contrary perhaps to what one might expect, the appetite is unusually great. The cases in question usually terminate favourably, and belong, I presume, to the class of jaundice from mechanical impediment, and especially to the variety arising from catarrh of the biliary ducts; but I think I have observed it also in the early stages of some cases of cancer of the head of the pancreas, causing jaundice by pressure on the duct; and here Frerichs, at all events, does not contradict me. On the other hand, in jaundice with much constitutional disturbance, the appetite is greatly impaired. There should, one would say, be an appropriate difference in the dietary of these two classes, as well as in their medical treatment. The ravening in the former class arises probably from the stoppage or great diminution of the absorption of fat by the lacteals, through loss of the emulsifying agency of the bile, or it may be partly also, according to Liebig's theory, because the supply of carbon for oxidation is lessened through the deficient passage of bile. On the former supposition, here is a field for the employment of the pancreatic emulsion, together with a mixed diet constituted mainly on Frerichs's plan: it would seem, however, inexpedient fully to gratify the inordinate craving of the patient.

\section{OBSTETRIC MEMORANDA.}

\section{PROLAPSUS OF THE UTERUS CONTAINING A CHILD, BETWEEN THE SEVENTI AND EIGHTH MONTHS OF THE SECOND PREGNANCY.}

By William Allison, Esq., East Retford.

A CASE of extroversion of the uterus with placenta, related (in the Lancet of February 6th, I 869) by Mr. Foster of Leeds, reminds me ot an occurrence which happened in my practice in the year 1838 .

On March 23rd, in attending upon a woman, I found the uterus, containing a child, in the bed, just as if the child had been born. After sponging off any trifles of lint, etc., from the uterus, the entire mass was carefully returned into the abdomen of the mother. On March 24 th, a pessary was introduced, and each day, for three days, one of a different kind; but as all were intolerable, the woman was desired to lie or sit until labour came on. On May 2nd, after a lingering labour, the child was born and is now living--a healthy man in Sheffield. In 1844 , a second son was born; both he and his mother are now living in this town. 